\title{
Digital Natives and Freedom of Speech on Social Media in Indonesia
}

\author{
Adya Paramita Prabandari ${ }^{1}$ \\ \{adyapprabandari@gmail.com ${ }^{1}$ \} \\ Faculty of Law, Universitas Diponegoro, Jl. Prof. Soedarto, SH., Tembalang, Semarang, Indonesia \\ 50275
}

\begin{abstract}
The rapid development of information and communication technology in the globalization era brought the Digital Revolution, such as the invention of the internet, and the creation of various kinds of internet-based social media. This eventually results in the birth of a generation called digital natives, i.e. a generation born and growing in the midst of the development and sophistication of the internet and gadgets, so for them, digital technology is an integral part of life and everyday life that cannot be separated. However, we must be aware of the excessive use of internet-based social media. This because they feel that they have unlimited freedom in conveying various opinions, information, and ideas in the form of various statuses on social networks, which they consider as their private territory. They don't seem to realize that by uploading statuses on various social networks, these statuses will be accessible to all other internet users from all over the world, and can have various positive and negative impacts, including the possibility of the occurrence of violence/serious threats to national security. This becomes the responsibility of the state to regulate and supervise digital natives so that they can use the internet responsibly in accordance with moral ethics and laws in Indonesia.
\end{abstract}

Keywords: digital natives, freedom of speech, social media.

\section{Introduction}

Information and communication technology continues to develop very rapidly from prehistoric times to the present. This is in line with the main needs of humans as social creatures to interact with each other, so that in order to fulfill these needs and to further simplify and accelerate human interaction, humans continue to strive to create new technological innovations in the field of information and communication. These innovations are not only limited to the tools, but also the information and communication networks.

The development of information and communication technology is progressing rapidly in the era of globalization, which is marked by the beginning of a very rapid and fundamental change in the order of human life through the Three $\mathrm{T}$ Revolution (Transportation, Telecommunications and Tourism).[1]

This in line with Alvin Toffler [2][3], who argues that there are 3 social waves that change human civilization and culture in general, where the Third Wave civilization is the Information Age or the Knowledge Age, begins with the Digital Revolution ("the change from analog, mechanical, and electronic technology to digital technology ...") which lasted from the late 1950 s to the present. This revolution drastically changes the way a person views life and causes major changes throughout the world. Many very important discoveries have occurred 
in this era, such as the invention of computers with technology and increasingly compact forms, the invention of the internet, and the creation of various kinds of internet-based social media.

With the rapid development of the internet, which according to S.K. Tambyah [4], [5] has 3 characters, namely: (1) space / time compression; (2) no sense of place; and (3) blurred boundaries and transformed communities; as a supporter of the growing interaction and increasingly rapid rate of information in the globalization era, coupled with the support of the development of information and communication technology, in the form of increasingly sophisticated gadgets, a community in cyberspace is formed, consisting of what is called net generation [6], [7] or digital natives, as a new type of global community.

Digital Natives is a generation that grew up primarily by the mass media and the internet, which was born after the 1980s, where the internet began to be widely used by the public. This generation is a generation that grows with the setting of information technology developments, especially mobile phones and the internet, which can bring the younger generation to roam the world in a virtual world without borders. [8]

The aim of this study is to find out how digital natives practice freedom of speech in using social media in Indonesia.

\section{Method}

The method used in this research is normative juridical method "which is performed by examining the data library materials is secondary".[9] This study combines the two approaches, the statute approach and conceptual approach.[10] The data used and analyzed in this research is secondary data which is made legal and non-legal material, which was collected by using literature and document research. [11] The data obtained in this study were selected and arranged systematically to be analyzed and elaborated further with qualitative analysis method. [12]

\section{Results}

\subsection{Social Media and Digital Natives}

Social Media. Social media [13] is "a group of Internet-based applications that build on the ideological and technological foundations of Web 2.0, and that allow the creation and exchange of user-generated content". Meanwhile, the Merriam-Webster Dictionary defines social media as "forms of electronic communication (such as websites for social networking and microblogging) through which users create online communities to share information, ideas, personal messages, and other content (such as videos)"'[10]. Some examples are social networking such as Facebook and LinkedIn; media sharing such as YouTube, Instagram and TikTok; and personal online diary in the form of a blog (Blogspot, WordPress) and microblog (Twitter).

The presence of social media in cyberspace has resulted in very radical and significant changes in the patterns and ways of communicating in society. This latest communication technology has attracted public attention because of the many benefits it can take. Moreover, 
this communication technology can be seen, used, and utilized so easily using a cell phone, which we now know as a "smartphone" which nowadays can be owned by everyone easily and cheaply. The widespread use of social media, especially among young people, gave birth to the era of the end of geography, because it causes this world to seem to be borderless, where the dissemination of information about events that occur in one place can be quickly accepted by people in other parts of the world.

Digital Natives. The use of social media which is supported by sophisticated information and communication technology devices (gadgets) is so easy that it eventually results in the birth of a generation called "Millenials", "Net Generation", "Gen Y", or "digital natives". Digital Natives is a generation that grew up and raised mainly by the mass media and the internet, which was born after the 1980s, when the internet began to be widely used by people. According to Prensky [14], digital natives constitute "an ever-growing group of children, adolescents, and nowadays young adults (i.e. those born after 1984; the official beginning of this generation) who have been immersed in digital technologies all their lives.[15] Prensky also said that digital natives is "a person who was born during or after the general introduction of digital technology, and through interacting with digital technology from an early age, has a greater understanding of its concepts".[16]

So digital natives are a generation born and growing in the midst of the development and sophistication of the internet and gadgets, so that for them digital technology is an integral part of life and everyday life that cannot be separated. Surfing in cyberspace, downloading songs or videos from YouTube, accessing Facebook, Twitter, Instagram and others are part of their daily lives and have become a lifestyle. Digital natives can access news and updates from anywhere in the world quickly and relatively instantaneously (real time), so that there is no longer a gap between distance and time. Whether we admit it or not, the internet or social networks in cyberspace have the potential to radically change not only the way a person interacts, communicates or transacts with others, but also changes the nature of human existence in society.[17]

\subsection{Freedom of Speech}

Freedom of speech owned by every human being as part of their human rights. Freedom of speech is stated in Article 19 of the Universal Declaration of Human Rights (UDHR) that "Everyone has the right to freedom of opinion and expression; this right includes freedom to hold opinions without interference and to seek, receive and impart information and ideas through any media and regardless frontiers." This guarantee of freedom of opinions and expression (further referred to as freedom of speech) is strengthened by the International Covenant on Civil and Political Rights (ICCPR) particularly in Article 19:

“ (1) Everyone shall have the right to hold opinions without interference.

(2) Everyone shall have the right to freedom of expression; this right shall include freedom to seek, receive and impart information and ideas of all kinds, regardless of frontiers, either orally, in writing or in print, in the form of art, or through any other media of his choice.

(3) The exercise of the rights provided for in paragraph 2 of this article carries with it special duties and responsibilities. It may therefore be subject to certain restrictions, but these shall only be such as provided by law and are necessary:

(a) For respect of the rights or reputations of others;

(b) For the protection of national security or of public order (ordre public), or of public health or morals." 
In terms of the provisions of Article 19 of the UDHR and Article 19 of the ICCPR, the right to freedom of speech is not limitless in its fulfillment and implementation. There must be restrictions on the fulfillment and exercise of the rights to freedom of speech established by law and for the purposes of respecting the rights and good names of others, and for maintaining national security or public order or public health and morals. However, the restrictions imposed on the right to freedom of speech should not be arbitrary. Furthermore, in the Siracusa Principles on the Limitation and Derogation Provisions in the International Covenant on Civil and Political Rights [18] is stated that "The scope of a limitation refereed to in the Covenant shall not be interpreted so as to jeopardize the essence of the right concerned". So all limitation clauses must be interpreted explicitly and aim to support the related rights. This is an affirmation that the restrictions imposed on the rights set out in the ICCPR, in particular the right to freedom of speech, cannot be arbitrary.

One of the restrictions placed on the right to freedom of speech relates to national security. The principles of limitation on the basis of national security reasons are further discussed in detail in the Johannesburg Principles on National Security, Freedom of Expression and Access to Information.[19] In the Johannesburg Principles, it is stated that a form of freedom of opinion and expression can be assessed as a threat to national security only if the government can show evidence that the expression is intended to motivate serious violence / threat that will occur, can motivate serious violence / threat, or there is a connection directly between the expression and the possibility of the occurrence of violence / serious threats to national security.

\section{Discussion}

The advancement of information and communication technology in the form of the Internet is like a double-edged sword. On the one hand, the internet has opened wide windows of information so that it is easy for humans to share and also get information from various parts of the world quickly in real time and as if it is borderless. But on the other hand, internet access creates a new problem that is quite complicated, namely in terms of digital natives who feel they have unlimited freedom and tend to be uncontrollable in expressing their opinions, regardless of politeness, decency, and possible violations of the rights and reputation of others.

Digital natives convey various opinions, information and ideas using internet-based social media that we must pay attention to and be aware of. It must be admitted that the current use of internet-based social media tends to be excessive, because digital natives feel that they have unlimited freedom in conveying various opinions, information, and ideas in the form of various statuses on social networks, which they consider as domains or their private territory. They don't seem to realize that by uploading statuses on various social networks, these statuses will be accessible to all other internet users from all over the world, and can have various positive and negative impacts.

Freedom of speech in Indonesia began to get a breath of fresh air since the fall of Soeharto and the start of the Reformation era in 1998. The taps of freedom of speech seemed to be pouring out profusely. The freedom to access, upload and receive various information is widely opened and is greatly enjoyed by all levels of society, including digital natives. In relation to the right to freedom of speech as part of Human Rights, the Government has a position as a duty bearer which includes 3 obligations: obligation to respect, obligation to fulfill, and obligation to protect.[20] These three obligations have been carried out by the 
Indonesian government seen in various laws and regulations relating to the fulfillment and implementation of the right to freedom of speech as follows:

1. The 1945 Constitution of the Republic of Indonesia

In the 1945 Constitution of the Republic of Indonesia Article 28 E Paragraph (3) it is stated that "Every person shall be entitled to freedom to associate, to assemble, and of expression". Furthermore, Article $28 \mathrm{~F}$ states that "Every person is entitled to communicate and to obtain information for the development of his/her personality and social environment, as well as be entitled to seek, to obtain, to own, to store, to process, and to convey information by means of all kinds of available channels".

With the existence of these two articles in the Constitution, the Government firmly recognizes the right to freedom of opinion and expression owned by every Indonesian citizen. Therefore, the Government has an obligation to accommodate and protect the rights to freedom of opinion and expression that are owned by every Indonesian citizen.

2. The Electronic Information and Transaction Law

The Government of the Republic of Indonesia has enacted the Law Number 11 of 2008 concerning Electronic Information and Transaction which was later amended by Law Number 19 of 2016 concerning the Amendments to Law Number 11 of 2008 concerning Electronic Information and Transaction. Article 3 explicitly states that the use of information technology and electronic transactions is carried out based on the principles of legal certainty, benefits, cautiousness, good faith, and freedom to choose technology or technology neutrality. Furthermore, Article 4 states that the use of information technology and electronic transactions must be carried out with the aim of:

a. Educating the nation's life as part of the world information society;

b. Developing trade and the national economy in order to improve people's welfare;

c. Increase the effectiveness and efficiency of public services;

d. Opening the widest possible opportunity for everyone to advance their thinking and abilities in the field of use and utilization of information technology optimally and responsibly; and

e. Provide a sense of security, justice and legal certainty for users and operators of information technology.

Based on the principles and objectives mentioned above, the EIT Law has strictly regulated the prohibited acts within the scope of the use and utilization of information and communication technology, and criminal sanctions against the perpetrators of these violations have also been regulated. Especially with regard to online bullying or cyberbullying, negative campaigns and black campaigns, or various kinds of status, statements, videos, or memes that are made by digital natives that contain elements of ethnicity, religion, race and intergroup (further referred as SARA), or words which is rude, disrespectful, and indecent, which aims to threaten, blackmail, defame, slander, or attempt to assassinate someone's character is regulated in Article 27 paragraph (1), (3) and (4); Article 28 paragraph (2); and Article 29. For the perpetrators of violations of the articles mentioned above, there are also criminal provisions that are regulated in Article 45 paragraph (1), (3), and (4); Article 45A paragraph (2); and Article 45B.

From the several articles described above, it can be concluded that these are the rules in Indonesian law regarding restrictions on the right to freedom of opinion and expression in cyberspace in the form of various content (status, comments, photos, and videos) on various social media.

In accordance with one of the objectives of the Unitary State of the Republic of Indonesia as stated in Paragraph 4 of the Preamble of the 1945 Constitution of the Republic of 
Indonesia, namely "... to form a Government of the State of Indonesia which shall protect the whole Indonesian nation and the entire native land of Indonesia, ...", and related to the statement from John Stuart Mill that more or less said "freedom of expression is needed to protect citizens from corrupt and tyrannical rulers / governments". Therefore, in a democratic country, citizens can participate in choosing their government, and provide input in decision making, and provide an assessment of the government's performance. However, freedom of opinion and expression must still be responsible and not be a potential threat to the lives of others. Mill further said that "even opinions lose their immunity when the circumstances in which they are expressed are such as to constitute their expression a positive instigation to some mischievous act", namely that an opinion can lose its immunity (freedom) if stated in the intent or circumstances that instigate and can give rise to evil actions.

Therefore, restrictions on the right to freedom of opinion and expression (freedom of speech) are absolutely necessary, especially in terms of freedom of opinion and expression which can lead to propaganda and provocation that can lead to war, and against all actions that promote hatred and are incitement to discriminate on the basis of SARA.

However, various obstacles in the implementation of regulation and supervision of digital natives' freedom of speech in cyberspace still exist, including:

a. The digital natives' lack of understanding of what is allowed and should not / is prohibited to be written, uploaded, or disclosed in cyberspace

Digital natives freely write status and comments on various social media that contain racial elements, as well as harsh, disrespectful and indecent words, which aim to threaten, blackmail, defame, slander, or attempt character assassination against someone. Sometimes it can even be classified as a form of provocation and motivation for violence on the basis of SARA, which can result in disruption of public order and national security. This is due to, among other things, the lack of understanding that digital natives members have about what is allowed and shouldn't / is prohibited to be written, uploaded, or disclosed in cyberspace.

b. The lack of supervision by the Government of Indonesia on various content in cyberspace.

So far, the Indonesian government, in this case the Ministry of Communication and Information, seems to have only focused and focused attention on finding and blocking various pornographic sites in cyberspace. However, various content that contains elements of racial violence, as well as harsh, disrespectful and indecent words, which aim to threaten, blackmail, defame, slander, or attempt to assassinate someone's character, which is a provocation and motivation for violence against the basis of SARA, it seems that it has received little or no attention from the Government.

\section{Conclusion}

The use of information and communication technology has changed the behavior of society and human civilization globally. The development of information and communication technology has made the world appear borderless, resulting in increasingly rapid political, economic, social and cultural changes. The development of the internet and various internetbased social media resulted in the birth of the digital generation or net generation or digital natives. Digital natives are a generation born and growing in the midst of the development and sophistication of the internet and gadgets, so for them digital technology is an integral part of life and everyday life that cannot be separated. However, we must be aware of the excessive 
use of internet-based social media. This because digital natives sometimes feel that they have unlimited freedom in conveying various opinions, information, and ideas in the form of various statuses on social networks, which they consider as domains or their private territory. They don't seem to realize that by uploading statuses on various social networks, these statuses will be accessible to all other internet users from all over the world, and can have various positive and negative impacts, including the possibility of the occurrence of violence / serious threats to national security.

The Government of the Republic of Indonesia has actually strictly regulated the digital natives activities in cyberspace with the Law Number 11 of 2008 concerning Electronic Information and Transaction which was later amended by Law Number 19 of 2016 concerning the Amendments to Law Number 11 of 2008 concerning Electronic Information and Transaction. However, various obstacles in the implementation of regulation and supervision of digital natives' freedom of speech in cyberspace still exist, including the digital natives' lack of understanding of what is allowed and should not / is prohibited to be written, uploaded, or disclosed in cyberspace; and the lack of supervision by the Government of Indonesia on various content in cyberspace.

Thus the author recommend the followings:

1. The inclusion of content on internet education into the national education curriculum to ensure that students (in this case the young generation of the nation who are part of digital natives) receive guidance and direction on how to use the internet properly and correctly according to moral and legal ethics. This is done with the hope that the younger generation of digital natives will be able to make smart use of the internet and various social media for positive purposes as much as possible, and can minimize the negative influence of various content on the internet so as not to harm in the future.

2. The implementation of a filtering system against various sites and content on the internet that are indicated or proven to spread racial hatred, discrimination or radicalization, especially those that openly provoke crimes or violence based on SARA. It can also open a special mechanism that can be used by digital natives to report if they find various sites or content on the internet that are indicated or proven to spread racial hatred, discrimination or radicalization, and are accompanied by evidence.

3. A fair and transparent legal process is carried out, if there are reports of various sites or content on the internet that are indicated or proven to spread racial hatred, discrimination or radicalization, especially those that openly provoke crimes or violence based on SARA.

4. For the internet user figures (influencers, youtubers etc.) who are quite influential in cyberspace and has a large number of followers, to provide educational and knowledgerelated information, especially regarding what should and should not be done or ethics using internet-based social media that is appropriate and in accordance with morals and applicable laws in Indonesia.

\section{Acknowledgments}

Acknowledgments. The author is very grateful to the Dean and Vice Deans of the Faculty of Law, Universitas Diponegoro, for all the support and financial assistance from the 2020 fiscal year. 


\section{References}

[1] A. P. Prabandari, P. Susetyorini, and D. Hartono, "The urgency of ratification of the 2010 Beijing convention concerning enforcement of unlawful acts against international civil aviation," Acad. J. Interdiscip. Stud., vol. 9, no. 2, pp. 31-35, 2020.

[2] Q. B. Baloch and N. Kareem, "The Third Wave," J. Manag. Sci., vol. I, no. 2, pp. 115-143, 2007.

[3] J. Sitompul, Cyberspace, Cybercrimes, Cyberlaw: Tinjauan Aspek Hukum Pidana. Jakarta: PT. Tatanusa, 2012.

[4] S. K. Tambyah, "Life on the Net: the Reconstruction of Self and Community," Adv. Consum. Res., vol. 23, pp. 172-177, 1996.

[5] R. Rettie, "Net Generation Culture," J. Electron. Commer. Res., vol. 3, no. 4, pp. 254-264, 2002.

[6] D. Tapscott, Growing Up Digital: The Rise of the Net Generation. New York: McGrwa-Hill, Inc., 1998

[7] M. Akçayir, H. Dündar, and G. Akçayir, "What makes you a digital native? Is it enough to be born after 1980?," Comput. Hum. Behav., vol. 60, pp. 435-440, 2016.

[8] R. Sugihartati, Perkembangan Masyarakat Informasi \& Teori Sosial Kontemporer, I. Jakarta: Kencana, 2014.

[9] R. H. Soemitro, Metodologi Penelitian Hukum dan Jurimetri. Jakarta: Ghalia Indonesia, 1990.

[10] J. Ibrahim, Teori \& Metodologi Penelitian Hukum Normatif. Malang: Bayumedia Publishing, 2006.

[11] P. M. Marzuki, Penelitian Hukum, 1st ed. Jakarta: Kencana, 2005.

[12] M. F. ND and Y. Achmad, Dualisme Penelitian Hukum Normatif dan Empiris. Yogyakarta: Pustaka Pelajar, 2010.

[13] A. M. Kaplan and M. Haenlein, "Users of the world, unite! The challenges and opportunities of Social Media,” Bus. Horiz., vol. 53, no. 1, pp. 59-68, 2010.

[14] P. A. Kirschner and P. De Bruyckere, "The myths of the digital native and the multitasker," Teach. Teach. Educ., vol. 67, pp. 135-142, 2017.

[15] W. Minghui, "5.1 Digital Natives vs. Digital Immigrants." [Online]. Available: https://wiki.nus.edu.sg/display/SPORE/5.1+Digital+Natives+VS+Digital+Immigrants. [Accessed: 04-Aug-2015].

[16] M. Prensky, "Digital Natives, Digital Immigrants," Horiz., vol. 9, no. 5, 2001.

[17] P. DiMaggio, E. Hargittai, W. R. Neuman, and J. P. Robinson, "Social Implications of the Internet," Annu. Rev. Sociol., vol. 27, pp. 307-336, 2001.

[18] American Association of International Comission of Jurists, "Siracusa Principles on the Limitation and Derogation Provisions in the International Covenant on Civil and Political Rights.” [Online]. Available: https://www.icj.org/wp-content/uploads/1984/07/Siracusaprinciples-ICCPR-legal-submission-1985-eng.pdf. [Accessed: 17-Aug-2020].

[19] I. S. Series, "The Johannesburg Principles on National Security, Freedom of Expression and Access to Information," in Access, London: Article 19, 1996.

[20] M. Nowak, Introduction to the International Human Rights Regime. Leiden: Martinus Nijhoff, 2003. 